\section{New Trends and Issues Proceedings on Humanities and Social Sciences}

Volume 6, Issue 3 (2019) 050-057

www.prosoc.eu

Selected Paper of 8th World Conference on Business, Economics and Management (BEM-2019) 26 - 28 April 2019, Grand Park Lara Hotel Convention Center, Antalya, Turkey

\title{
The effect of psychological capital and emotions on emotional labour: A study on hotel employees
}

Selin Donmez*, Yildiz Technical University, Institute of Social Sciences, Istanbul, Turkey

Serdar Bozkurt, Yildiz Technical University, Faculty of Economics and Administrative Sciences, Department of Business Administration, Istanbul, Turkey

\section{Suggested Citation:}

Donmez, S. \& Bozkurt, S. (2019). The effect of psychological capital and emotions on emotional labour: A study on hotel employees. New Trends and Issues Proceedings on Humanities and Social Sciences. [Online]. 6(3), pp 050-057. Available from: www.prosoc.eu

Selection and peer review under responsibility of Prof.Dr. Cetin Bektas, Gaziosmanpasa University, Turkey. ${ }^{\circ} 2019$ United World Center of Research Innovation and Publication. All rights reserved.

\begin{abstract}
The primary purpose of this research is an investigation of the influence of psychological capital and emotions on emotional labour. Importance of this research is to conduct the literature and drawing attention effects of psychological capital on the relevance among the emotions and emotional labour to catch the attention of administrators. In this study, the impact of psychological capital and emotions on emotional labour is researched with employees working in the hospitality sector, which includes intense emotional labour. In this study, a questionnaire which is one of the quantitative decision techniques is used to collect necessary data. The consequence of the research demonstrates that psychological capital and emotions have an impact on emotional labour. In addition to that, hope which is one of dimensions of psychological capital and positive emotions affect emotional labour.
\end{abstract}

Keywords: Psychological capital, emotions, emotional labour.

\footnotetext{
* ADDRESS FOR CORRESPONDENCE: Selin Donmez, Master Student, Yildiz Technical University, Institute of Social Sciences, Istanbul, Turkey. E-mail address: selinddonmez@gmail.com / Tel.: +900212 3837070
} 


\section{Introduction}

In today's modern world, companies from varied sectors exhibit competitive behaviour to succeed. As time passes and companies start to compete with each other, they began to differentiate their products or service with value-adding activities. Although some industries prefer to develop their products, service sectors choose to differentiate their service by controlling their employees' emotions. In these sectors, emotional display rules are used to maximise customer satisfaction and improve service quality. On the other hand, this situation forced employees to demonstrate emotional labour in the workplace as requirements of their works.

Emotional labour is the term that is proposed by Hochschild in 1980 to the literature. Hochschild $(1983$, p. 7$)$ identifies the term emotional labour behaviour as images that are created by employees and observed by other people. According to the author, emotional labour behaviour is necessary for employees' job requirements and sellable service, which has a change value for them. Following Hochschild's study, Ashforth and Humphrey (1993), Morris and Feldman (1996), and Grandey (2000), Rodrigues, (2017) studied on emotional labour and contributed literature by defining strategies of emotional labour, antecedents of emotional labour, dimensions of emotional labour and conclusions of emotional labour.

There are three acting strategies of emotional labour, which are surface acting, deep acting and genuine acting. Surface acting means that presenting appropriate or desired emotions in the workplace by hiding or faking individuals' emotions (Diefendorff, Croyle \& Gosserand, 2005). Deep acting means that changing both inner emotions and physical expressions by using individuals' imaginations and experiences that may recall proper emotions to show appropriate expressions in the workplace (Chu \& Murrmann, 2006). The last acting strategy of emotional labor is genuine acting and means that expression of emotions that are naturally felt by individuals (Yin, Lee, Zhang \& Jin, 2013). In other words, individuals do not force themselves to change their original feelings to show appropriate emotions.

Emotional labour has both positive and negative outcomes. Positive outcomes of emotional labour are job satisfaction, high performance, high motivation, organisational citizenship behavior, physiological and psychological well-being of individuals, financial benefits, success in interpersonal skills and commitment to job (Oguz \& Ozkul, 2016). Even so, emotional labour's adverse outcomes are a sense of inauthenticity, loss of soul, desensitised self-esteem and burnout (Pugliesi, 1999).

Psychological capital is contributed to the literature with the studies of Luthans, Luthans and Luthans (2004), due to positive psychology. According to Seligman, Duckworth and Steen (2005), positive psychology is the science of positive expressions. With the help of positive psychology, psychological capital is defined as identifying humans' strengths and psychological sources to develop individuals, groups and organisations (Cavus \& Kapusuz, 2015; Rahiminejad, Golshani \& Arshi, 2018) The concept of psychological capital focuses on positive attitudes and feedbacks.

Studies show that there are four dimensions of psychological capital, such as self-efficacy, optimism, hope and resilience. They determined psychological capital's four aspects as self-efficacy, optimism, hope and resilience (Luthans et al., 2004). The first dimension of psychological capital is self-efficacy and means that to achieve goals, showing necessary performance and desire in challenging situations (Luthans, Avolio, Avey \& Norman, 2007). Second dimension optimism means that positive perspective to issues based on crucial aspects is permanent, desired and beneficial and negative ones are temporary, undesired and situation-based (Luthans \& Yousef, 2004). Hope is explained as a constructive state of mind based on accomplishment and planning to achieve regarding goals (Snyder, Sympson \& Ybasco, 1996). Last and fourth dimension is resilience; it expresses the positive psychological capacity in the face of difficulties, problems, failures and conflicts (Luthans, 2002). 
Emotion is the term that is studied by many researchers by years and hard to explain. Emotions generally revealed as it manages the cognitive, action and physiological expressions of individuals. The concept of emotions is defined as specific neuropsychological events that are embodied by survival of the fittest (Izard, 1992). Emotions constitute notions and notions that manage the actions of individuals. The term emotion has two dimensions, which are positive emotions and negative emotions. Although positive emotions are defined as feelings which give satisfaction to individuals, negative emotions are identified as feelings do not give any pleasure to individuals (Gencoz, 2000). Positive emotions contribute to individuals developments. It makes easier to learning and mulling over and develops human relations. Also, they have an important role on decision-making, being openminded, adaptation and creativity (Lyubomirski, King \& Diener, 2005). Individuals who have negative affection have negative perspective in their lives and they have low confidence (Can, Coban \& Soyer, 2011). Positive emotions are determined as emotions, such as happiness, interest, demand, confidence and negative ones are like anger, stress and fear (Watson \& Clark, 1988).

Previous studies show that psychological capital affects emotional labour. Individuals who have a high echelon of psychological capital force themselves to show deep acting instead of surface acting (Hurr, Rhee \& Ahn, 2015). Also, research conducted by Begenirbas (2015) shows that a high level of psychological capital of employees influence surface and deep acting behaviour of individuals negatively and surface acting behaviour positively in the health sector. In addition to that, there is not an essential relationship between hope and emotional labour (Alamur \& Atabay, 2016). The research conducted by Synder, Irving and Anderson (1991) signalise that there is a negative relationship between hope and anxiety, which is one of the negative emotions.

The tourism sector is one of the areas in which employees exhibit emotional labour widely. In this industry, employees are generally in touch with their guests and are responsible for their high level of satisfaction. To maximise the comfort of guests and give the best service to them, they generally put emotional labour in response to their job requirements. Due to this situation and to get better findings, this study is conducted in the tourism sector.

\section{Purpose and significance of the research}

The object of this study is to search the influence of emotions and psychological capital on emotional labour. This study is vital for literature since there is not any academic research from the perspective of these three dimensions. This study might guide further studies. Moreover, this study might help human resources experts in their employee selection and evaluation process, diminishing negative effects of emotional labour on employees' psychology and better understanding their employee's behaviours.

\section{Data gathering technique}

The questionnaire which consists of five sections is used. The first section was the cover letter explaining the target of the research and providing necessary information to participants. The second section of the questionnaire consists of six demographic questions identifying participants' gender, marital status, age, education level, tenure at the present job and position in the company. The third section includes emotional labour scale with 13 items, which is developed by Diefendorff et al. (2005) and translated to Turkish by Basim and Begenirbas (2012). The fourth section of the questionnaire involves psychological capital scale with 24 items that are developed by Luthans et al. (2007) and translated to Turkish by Cetin and Basim (2012). The last section was positive and negative emotions scale contains of 20 items, which is developed by Watson, Clark and Tellegen's (1988) and translated to Turkish by Gencoz (2000). Participants evaluated items on 5 points Likert Scale. These scales illustrate $1=$ Never 2 = Rarely, $3=$ Sometimes, $4=$ Most of the time, $5=$ Always for emotional labour scale. For Scale of Psychological Capital, 1 = Totally Disagree, $2=$ Disagree, $3=$ Neither Agree Nor 
Disagree, $4=$ Agree and $5=$ Totally Agree are illustrated. For Scale of Emotions, Likert Scale is $1=$ Never, 2 = A little, $3=$ Medium, $4=$ Quiet and 5= Too much.

Cronbach alpha reliability values of the scales used in this study are calculated. The Cronbach alpha value is found to be 0.830 for 13 -items on the emotional labour scale, 0.956 for 24 items on the psychological capital scale, 0.826 for the ten positive emotions expression and 0.796 for the negative emotions' appearance on the emotions scale.

\section{Research model}

The figure for the exploratory research model is shown in Figure 1.

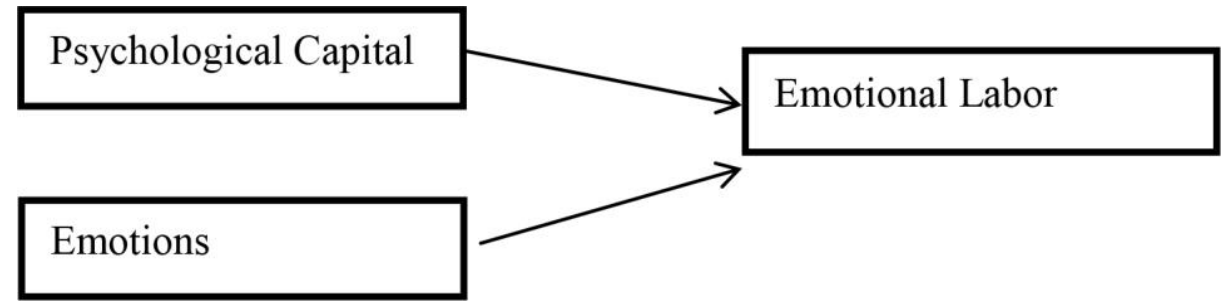

Figure 1. Conceptual framework

\section{Research sample}

To gather best data for this study and identify effect of emotions and psychological capital on emotional labor, 163 hotel employees from Istanbul and Kayseri were participated to this study and 158 of them is used for analysis of this study. Convenience sampling method is used to collect necessary data.

Demographic information of participants show that $38.61 \%$ of respondents were female and $61.39 \%$ were male. $21.94 \%$ of participants were graduated from elementary and high school, $23.87 \%$ of them have associate degree, $47.74 \%$ of participants have bachelor's degree and $6.46 \%$ of respondents have master's/ PhD degree. 32.06\% of participants have managerial role in their workplace and $67.94 \%$ of them are employee. $43.67 \%$ of participants are single and $56.33 \%$ of participants are married. $65.81 \%$ of participants are between age of 22 and 34 years, $25.16 \%$ of them between age of 35 and 44 years and $9.03 \%$ of them between age of 45 and 60 years. $37.18 \%$ of participants are working in their current workplace for between 0 and 1 year, $26.28 \%$ of them for 2-3 years, $24.36 \%$ of them $4-6$ years, $3.85 \%$ of them $7-10$ years, $4.49 \%$ of them for $11-15$ years and $3.85 \%$ of them are working in their current workplace for $16+$ years.

\section{Results and discussion}

Data were evaluated within $95 \%$ confidence range and $p<0.05$ level of significance.

Table 1 shows analysed descriptive statistics findings.

Table 1. Descriptive statistics

\begin{tabular}{lcc}
\hline & Mean & Std. Deviation \\
\hline Emotional labor & 3.19 & 0.76 \\
Surface acting & 2.61 & 1.00 \\
Deep acting & 3.51 & 1.23 \\
Genuine acting & 3.92 & 0.99 \\
Psychological capital & 4.09 & 0.59 \\
Hope & 4.10 & 0.64 \\
Self-efficacy & 4.33 & 0.70
\end{tabular}




\begin{tabular}{lll} 
Resilience & 4.04 & 0.67 \\
Optimism & 3.81 & 0.71 \\
Positive emotions & 3.63 & 0.76 \\
Negative emotions & 1.90 & 0.65 \\
\hline
\end{tabular}

According to descriptive statistics findings, mean scores show that participants;

In the statements of emotional labour, participants tended to respond to the question of 'neutral' with the mean value of 3.19. The participants responded that the emotional behaviour of dimension the surface acting is 'disagree' with the mean value of 2.61. For their deep acting with the mean value 3.51 and genuine acting with the mean value 3.92, they 'agree'. Participants responded that they agree with their psychological capital and dimensions. The calculated mean value of psychological capital is 4.09 means that participants tended to respond 'agree' to questions. Participants respond on dimensions of psychological capital which are hope (mean value 4.10), self-efficacy (mean value 4.33), resilience (mean value 4.04) and optimism (mean value 3.81 ) as 'agree'.

For positive feelings, agree with the mean value of 3.63. For negative emotions, evaluations were made as to disagree with the mean value of 1.90 .

In the light of above figures, first hypothesis was generated.

H1: There is a particular relationship between psychological capital and dimensions, emotions and dimensions and emotional labour and dimensions.

Table 2. Correlations table between variables and dimensions

\begin{tabular}{|c|c|c|c|c|c|c|c|c|c|c|c|}
\hline Variables & 1 & & 3 & 4 & 5 & 6 & 7 & 8 & 9 & 10 & 11 \\
\hline Emotional labour (1) & 1 & & & & & & & & & & \\
\hline Surface acting (2) & $0.774^{* *}$ & 1 & & & & & & & & & \\
\hline Deep acting (3) & $0.830^{* *}$ & $0.398^{* *}$ & & & & & & & & & \\
\hline Genuine acting (4) & $0.377^{* *}$ & -0.116 & $0.292^{* *}$ & 1 & & & & & & & \\
\hline Psychological capital (5) & $0.359^{* *}$ & $0.189^{*}$ & $0.248^{* *}$ & $0.399^{* *}$ & & & & & & & \\
\hline Hope (6) & $0.390^{* *}$ & $0.185^{*}$ & $0.289^{* *}$ & $0.440^{* *}$ & $0.898^{* *}$ & 1 & & & & & \\
\hline Self-efficacy (7) & $0.325^{* *}$ & $0.208^{* *}$ & $0.221^{* *}$ & $0.291^{* *}$ & $0.934^{* *}$ & $0.824^{* *}$ & & & & & \\
\hline Resiliency (8) & $0.280^{* *}$ & $0.192^{*}$ & 0.155 & $0.283^{* *}$ & $0.838^{* *}$ & $0.614^{* *}$ & $0.731^{* *}$ & 1 & & & \\
\hline Optimism (9) & $0.230^{* *}$ & 0.030 & $0.190^{*}$ & $0.387^{* *}$ & $0.766^{* *}$ & $0.643^{* *}$ & $0.622^{* *}$ & $0.490^{* *}$ & 1 & & \\
\hline Positive emotions (10) & $0.346^{* *}$ & 0.111 & $0.327^{* *}$ & $0.382^{* *}$ & $0.540^{* *}$ & $0.506^{* *}$ & $0.493^{* *}$ & $0.479^{* *}$ & $0.362^{* *}$ & 1 & $-0.441^{* *}$ \\
\hline Negative emotions (11) & $-0.207^{* *}$ & -0.082 & $-0.209^{* *}$ & ${ }^{*}-0.171^{*}$ & ${ }^{*}-0.218^{* *}$ & $-0.176^{*}$ & ${ }^{*}-0.217^{* *}$ & $-0.244^{* *}$ & -0.090 & $-0.441^{* *}$ & 1 \\
\hline
\end{tabular}

As Table 2 offers that there is an important and positive relationship between emotional labor and psychological capital $(r: 0.359 ; p:<0.01) \mathrm{H} 1$ is supported. The relationships between emotional labour and dimensions of psychological capital are as follows: Hope $(r=0.39 ; p<0.05)$, self-efficacy $(r=0.32$; $p<0.05)$, resiliency $(r=0.28, p<0.05)$ and optimism $(r=0.23 ; p<0.05)$.

In this direction, there was a positive relationship between emotional labour and psychological capital dimensions between low and medium level. In addition, negative relationships between positive emotions and positive emotions $(r=0.34, p<0.05)$ and negative emotions $(r=-20, p<0.05)$ were determined.

In consideration of previous research studies (Alamur \& Atabay, 2016; Hulsheger \& Schewe, 2011; Snyder, Irving \& Anderson, 1991; Tamer, 2015) second hypothesis has been hypothesised.

H2: Hope and positive emotions affect emotional labour behaviour.

Multiple regression analysis was used to detect the extent to which hope and positive emotions predict emotional labour behaviour (Table 3). Findings from the regression analysis indicate that hope and positive emotions explain emotional labour at a statistically significant level $\left(R^{2}=0.15, F=27,953\right.$; $p<0.05)$. 
In terms of the variables entered into the regression equation, the hope variable $(B=.339, t=3.425$, $p<0.05)$ and positive emotions $(B=0.200, t=2.375, p<0.05)$ are significant

Table 3. Results of multiple regression analysis for emotional labour

\begin{tabular}{lccccc}
\hline & $\boldsymbol{B}$ & SE & Beta & $\boldsymbol{t}$ & $\boldsymbol{p}$ \\
\hline Hope & 0.339 & 0.099 & 0.289 & 3.425 & 0.001 \\
positive emotions & 0.200 & 0.084 & 0.200 & 2.375 & 0.019 \\
$R^{2}$ & 0.189 & $F$ & 1.296 & & \\
\hline
\end{tabular}

The results of the multiple regression analysis of emotional labour show that this model is significant with 5,642 significance level $0.00<0.05$. In this model, emotional labour is dependent variable and hope and positive emotions. When Adjusted $R$ Square figure is examined, hope and positive emotions can describe $17 \%$ of emotional labour together. Table 3 shows that a one unit increase in hope will increase emotional labour for 0.289 units. Also, a one unit increase in positive emotions will increase emotional labour for 0.200 units. These results demonstrate that $\mathrm{H} 2$ is accepted.

\section{Conclusion}

In today's modern world, many markets require emotional labour for customer satisfaction. Due to this situation, employees use more emotional labour acting strategies as time passes. First dimension of the study is emotional labour. Emotional labour was contributed to the literature in 1980 by Hochschild. The author explains emotional labour as individuals show images that can be observed by other individuals for financial benefits. Emotional labour can be expressed by three acting strategies which are deep, surface and genuine acting. There are many studies that reveal outputs of emotional labour. Second dimension of the study is psychological capital. Psychological capital was introduced to the literature by Luthans et al. (2004) by using positive psychology. Focal point of psychological capital is human strengths like positive attitude and experiences. There are four dimensions of psychological capital, such as optimism, hope, self-efficacy and resilience. Last and third dimension of the study is emotion. Emotions arrange individuals' notions and individuals shape their behaviours according to combination of their emotions and notions. Emotions have two dimensions which are positive and negative emotions. Psychological capital and emotions of employees have influences on emotional labor strategies. The relationship between emotional labour, emotions and psychological capital was tested on 158 hotel employees. According to the findings of this study, there is a significant relationship between emotional labour, positive and negative emotions and psychological capital.

This study primary aim is to analysing the effect of psychological capital and emotions on emotional labour. Importance of this study is that there is not any academic research combining these dimensions together, this study may provoke further research studies that will contribute to the literature and help human resources experts on employee selection and evaluation process and understand their employees better.

Tourism industry is the sector in which emotional labour is widely seen and employees working in this sector present emotional labour behaviour to maximise guests' satisfaction. Due to this situation, this study is conducted with 158 hotel employees located in Kayseri and Istanbul. For data collection, the questionnaire consists of five sections which are information, demographics, emotional labor scale, psychological capital scale and emotions scale was used. Findings of this study showed that there is a significant influence of psychological capital and emotions on emotional labour. Also, hope and positive emotions affect emotional labour significantly.

To contrast with previous research studies, findings of this study demonstrates that there is a significant relationship between psychological capital and emotional labour in parallel with research studies of Hulsheger and Schewe (2011), Hur et al. (2015) and Begenirbas (2015). In addition to that, 
unlike the research of Alamur and Atabay (2016), this research demonstrates that hope and positive emotions affect emotional labour. There are some methodological limitations that decrease the generalisability of the results of this paper. First data for this study is collected from only two cities of Turkey, which are Kayseri and Istanbul. Also, the data are collected in 1 month, and due to time limitation, it has not been possible to gather more data. Further studies may widen the scope of the sample to all the cities of Turkey and increase the number of respondents to improve legitimacy.

\section{References}

Alamur, B. \& Atabay, I. (2016). The relationship between emotional labour behaviour and psychological capital of employees: a study on banking sector. Press Academia Procedia, 2(1), 58-68. doi:10.17261/Pressacademia.2016118628

Ashforth, B. E. \& Humphrey, R. H. (1993). Emotional labor in service roles: the influence of identity. Academy of Management Review, 18(1), 88-115.

Basim, H. N. \& Begenirbas, M. (2012). Calisma yasamında duygusal emek: Bir olcek uyarlama calisması. Yonetim ve Ekonomi: Celal Bayar Universitesi Iktisadi ve Idari Bilimler Fakultesi Dergisi, 19(1), 77-90. Retrieved from http://dergipark.org.tr/yonveek/issue/13696/165760

Begenirbas, M . (2015). Psikolojik Sermayenin Calisanlarin Duygu Gosterimleri Ve Ise Yabancılaşmalarına Etkileri: Saglik Sektorunde Bir Arastirma. Süleyman Demirel Universitesi Iktisadi ve Idari Bilimler Fakültesi Dergisi, 20(3). Retrieved from http://dergipark.org.tr/sduiibfd/issue/20858/223751

Can, Y., Coban, U. \& Soyer, F. (2011). Negatif duygusalligin stres uzerindeki etkisi: faal futbol hakemleri uzerinde bir arastırma. Nigde Universitesi Beden Egitimi ve Spor Bilimleri Dergisi, 5(2), 165-174.

Cavus, M. \& Kapusuz, A. (2015). Psychological capital: definition, components and effects. British Journal of Education, Society \& Behavioural Science, 5(3), 244-255.

Cetin, F. \& Basım, H. N. (2012). Orgutsel psikolojik sermaye: Bir olcek uyarlama calismasi. Amme Idaresi Dergisi, 45(1), 121-137.

Chu, K. H. L. \& Murrmann, S. K. (2006). Development and validation of the hospitality emotional labor scale. Tourism Management, 27(6), 1181-1191. doi:10.1016/j.tourman.2005.12.011

Diefendorff, J. M., Croyle, M. H. \& Gosserand, R. H. (2005). The dimensionality and antecedents of emotional labor strategies. Journal of Vocational Behavior, 66(2), 339-357. doi:10.1016/j.jvb.2004.02.001

Gencoz, T. (2000). Pozitif ve negatif duygu olcegi: Gecerlik ve guvenirlik calisması. Turk Psikoloji Dergisi, 15(46), 19-26.

Grandey, A. A. (2000). Emotional regulation in the workplace: a new way to conceptualize emotional labor. Journal of Occupational Health Psychology, 5(1), 95.

Hochschild, A. R. (1983). The managed heart: commercialization of human feeling. California: University of California Press.

Hulsheger, U. R. \& Schewe, A. F. (2011). On the costs and benefits of emotional labor: a meta-analysis of three decades of research. Journal of Occupational Health Psychology, 16(3), 361. doi:10.1037/a0022876

Hur, W. M., Rhee, S. Y. \& Ahn, K. H. (2016). Positive psychological capital and emotional labor in Korea: the job demands-resources approach. The International Journal of Human Resource Management, 27(5), 477-500. doi:10.1080/09585192.2015.1020445

Izard, C. E. (1992). Basic emotions, relations among emotions, and emotion-cognition relations. Psychological Review, 99(3), 561-565.

Luthans, F. \& Yousef, C. (2004). Human, social, and now positive psychological capital management: investing in people for competitive advantage. Organizational Dynamics, 33(2), 143-160.

Luthans, F. (2002). The need for and meaning of positive organizational behavior. Journal of Organizational Behavior: The International Journal of Industrial, Occupational and Organizational Psychology and Behavior, 23(6), 695-706. doi:10.1002/job.165

Luthans, F., Avolio, B., Avey, J. \& Norman, S. (2007). Positive psychological capital: measurement and relationship with performance and satisfaction. Personnel Psychology, 60, 541-572. 
Luthans, F., Luthans, K. W. \& Luthans, B. C. (2004). Positive psychological capital: Beyond human and social capital. Business Horizones, 47(1), 45-50.

Lyubomirski, S., King, L. \& Diener, E. (2005). The benefits of frequent positive affect. Psychological Bulleting, 131(6), 803-855.

Morris, J. A. \& Feldman, D. C. (1996). The dimensions, antecedents, and consequences of emotional labor. The Academy of Management Review, 21(4), 986-1010.

Oguz, H. \& Ozkul, M. (2016). Duygusal Emek Surecine Yon Veren Sosyolojik Faktorler Uzerine Bir Arastirma: Bati Akdeniz Uygulaması. Süleyman Demirel Universitesi Vizyoner Dergisi, 7(16), 130-154.

Pugliesi, K. (1999). The consequences of emotional labor: effects on work stress, job satisfaction, and well-being. Motivation and Emotion, 23(2), 125-154.

Rahiminejad, P., Golshani, G. \& Arshi, M. (2018). The relationship between moral, supportive and oppressive leadership styles, with the psychological capital. Global Journal of Guidance and Counseling in Schools: Current Perspectives, 8(2), 67-76. doi:10.18844/gjgc.v8i2.3580

Rodrigues, A. (2017). The influence of academic and demographic factors on entrepreneurial intention antecedents among students of a Portuguese higher education institution. New Trends and Issues Proceedings on Humanities and Social Sciences, 4(1), 511-521. https://doi.org/10.18844/prosoc.v4i1.2294

Seligman, M., Duckworth, A. \& Steen, T. (2005). Positive psychology in clinical practice. Annual Review of Clinical Psychology, 1(1), 629-651. doi:10.1146/annurev.clinpsy.1.102803.144154

Snyder, C., Irving, L. \& Anderson, J. (1991). Hope and health: measuring the will and the ways. In Handbook of Social and Clinical Psychology (pp. 285-305).

Snyder, C., Sympson, S. \& Ybasco, F. (1996). Development and validation of the state hope scale. Journal of Personality and Social Psychology, 70(2), 321-335. doi:10.1037/0022-3514.70.2.321

Tamer, I. (2015). The effect of positive psychological capital on emotional labor. International Journal of Research in Business and Social Science, 4(2), 20-34. doi:10.20525/ijrbs.v4i2.23

Watson, D., Clark, L. A. \& Tellegen, A. (1988). Development and validation of brief measures of positive and negative affect: The PANAS scales. Journal of Personality and Social Psychology, 54(6), 1063-1070. doi:10.1037/0022-3514.54.6.1063

Yin, H.-b., Lee, J., Zhang, Z.-h. \& Jin, Y.-I. (2013). Exploring the relationship among teachers' emotional intelligence,emotional labor strategies and teaching satisfaction. Teaching and Teacher Education, 35, 137-145. doi:10.1016/j.tate.2013.06.006 